Int. J. Dev. Biol. 53: 891-894 (2009)

doi: $10.1387 / \mathrm{ijdb} .082815 \mathrm{mf}$

\title{
Primordial germ cell biology at the beginning of the XXI Century*
}

\author{
MASSIMO DE FELICl* \\ Department of Public Health and Cell Biology, University of Rome Tor Vergata, Rome, Italy
}

\begin{abstract}
At the XIV Workshop on the Development and Function of the Reproductive Organs held at the Congress Centre of the University of Rome Tor Vergata, Monteporzio Catone, Rome, Italy, the introduction to the first session entitled "Mammalian primordial germ cells" dedicated to the memory of Anne McLaren, was the occasion for a concise review of the state of art of research on the biology of primordial germ cells (PGCs). This great, unforgettable scientist, who died in a car accident in July 2007, dedicated most of her studies to this field over the last 25 years. Topics briefly reviewed in this Meeting Report are: 1) how the germ line is determined; 2) what are the mechanisms underlying PGC migration; 3) to what extent PGC survival, proliferation and differentiation are cell autonomous or environmentally controlled processes and 4) how the potential for totipotency is retained in PGCs.
\end{abstract}

KEY WORDS: primordial germ cell, epigenetics, cell migration, meiosis

At the XIV Workshop on the Development and Function of the Reproductive Organs held at the Congress Centre of the University of Rome Tor Vergata, Monteporzio Catone, Rome, Italy, the introduction to the first session entitled "Mammalian primordial germ cells"dedicated to the memory of Anne McLaren, was the occasion for a concise review of the state of art of research on the biology of primordial germ cells (PGCs). This great, unforgettable scientist, who died in a car accident in July 2007, dedicated most of her studies to this field over the last 25 years.

At the beginning of the 1980s, our understanding of the biology of mammalian PGCs was limited to the morphological description of their origin in the gonads, and their migration and differentiation within the gonadal ridges. In the early 1980s, Anne McLaren, as director of the MRC Mammalian Development Unit in London, decided to begin a series of studies aimed at identifying the cellular and the molecular bases of PGC development in the mouse. In an influential 1981 book entitled "Germ Cells and Soma: a new look to an old problem", (McLaren, 1983), Anne put forward and focused many of the main questions about PGC biology which were to be subsequently addressed by her and others working on mouse PGCs during the following years up to the present. Basically, the problems could be classified into the following topics: 1) how the germ line is determined in the early embryo; 2) the mechanism by which PGCs migrate from the site of their formation to the gonadal ridges; 3 ) the extent to which PGC survival, proliferation and differentiation is cell autonomous or controlled by environmental signals; the underlying signals and 4) how the potential for totipotency is retained in PGCs.

The period of PGC development in the mouse embryo lasts about 7 days from when around 7 days post coitum (dpc), PGC precursors located in the proximal posterior epiblast become committed to the germ line, to when PGCs around $13.5 \mathrm{dpc}$ differentiate within the gonads into oocytes or prospermatogonia (Fig. 1). During this period, crucial processes occur in PGCs at well defined times, including specification, migration, proliferation, entering into meiosis or epigenetic gene regulation, the latter occurring throughout the entire developmental period, so that PGCs can be regarded as a heterogeneous cell population

\footnotetext{
Abbreviations used in this paper: BMP, bone morphogenetic protein; CXCR4, CXC chemokine receptor 4; ECM, extracellular matrix; KL, KIT ligand; MIS, meiotic inducing substance; PGCs, primordial germ cells; MPS, meiosispreventing substance; OCT4, octamer4; PRDM1 or-14,PRdomain containing 1 or 14; PRMT5, protein arginine methyltransferase5; PTEN, phosphatase and tensin homolog; RA, retinoic acid; SF-1, splicing fator1; SMAD 1-5, mothers against decapentaplegic (MAD); Sox2, SRY sex determining region Y-box 2; SSEA-1, stage specific embryonic antigen -1; STRA8, stimulated by retinoic acid gene-8; TNAP, tissue non-specific alkaline phosphatase.
}

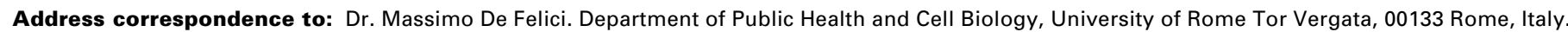
Fax: +39-067-259-6172. e-mail: defelici@uniroma2.it

\# Note: This paper is dedicated to Anne McLaren as a tribute.

Accepted: 25 November 2008. Published online: 19 June 2009.

ISSN: Online 1696-3547, Print 0214-6282

(c) 2009 UBC Press

Printed in Spain 
undergoing continuous change throughout all stages of their development.

\section{PGC specification}

This is certainly the topic in which the most impressive advances have recently occurred (for a review, see McLaren and Lawson, 2005; Hayashi et al., 2007). Briefly, we now know that at 5-6 dpc, the pluripotent proximal epiblast cells respond to bone morphogenetic protein (BMP) signals from extraembryonic tissues that primed them to become mesoderm cells. Roughly 12 hours later, about 6 clustered E-cadherin/fragilis expressing cells located in the posterior side of the proximal epiblast, receiving the highest dose of BMP-4 and expressing Smad1-5, are restricted to the germ cell lineage following Prdm1 (Blimp1) and Prdm14 expression. Finally, PGC precursors move along extraembryonic mesoderm cells at the base of the allantois where they are specified as PGCs following the expression of stella and other PGC markers such as TNAP, kit and SSEA-1 (Fig. 2).

At the genomic level, PGC specification involves at least three key events: repression of the somatic mesodermal program, reacquisition of potential pluripotency and genome-wide epigenetic reprogramming (Yamaji et al., 2008). PRDM1 associated to the methyltransferase PRMT5 seems to be critical for the repression of the somatic mesodermal program, likely through symmetrical methylation of arginine 3 on histones $\mathrm{H} 4$ and H2A. PRDM14 is essential for the reacquisition of potential pluripotency indicated by Sox 2 and Nanog expression and genomewide epigenetic reprogramming marked by several modifications of histones associated with a repressed or active chromatin state. OCT4 activated by a different way cooperates with SOX2 and nanog for pluripotency (Fig. 3).

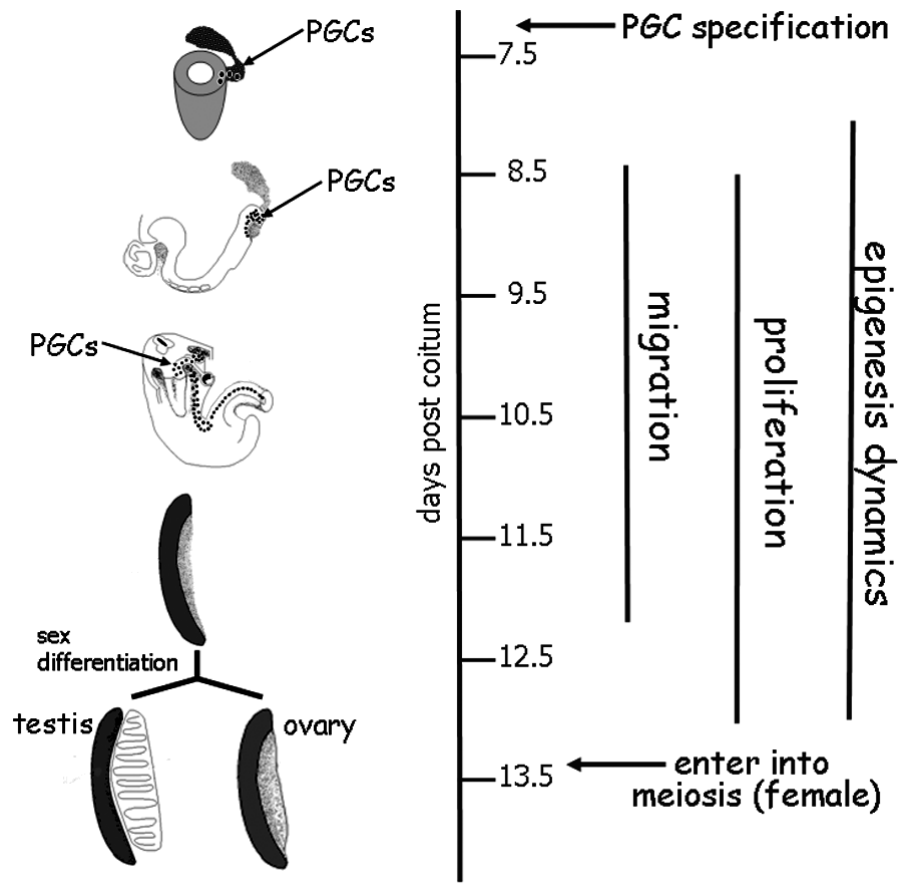

Fig. 1. Timetable of PGC development in the mouse embryo.

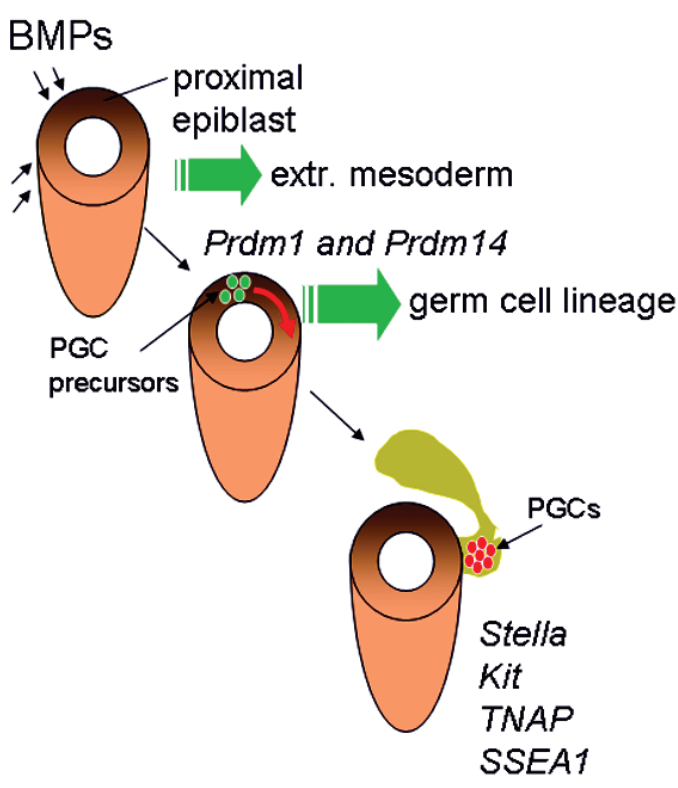

Fig. 2. Schematic representation of the main stages and processes of PGC specification in the mouse embryo.

\section{PGC migration}

There is still not a univocal view about the mechanisms of PGC migration and only scant information about their molecular motility machine is available (for reviews, see De Felici et al., 2005; SotoSuazo and Zorn, 2006). Passive and active movements, single and grouping movements, interaction with the extracellular matrix $(E C M)$, repulsive and attractive forces from the surrounding tissues; all these factors have been shown to be involved and likely play a role in this process. PGC migration can be schematically divided in three stages:

1) 8-9 dpc: PGCs move from the base of the allantois into the developing hindgut epithelium. E-Cad downregulation; Ifitm1 repulsive and Ifitm3 attractive homing in the hindgut epithelium, are all processes likely to play a role during this stage. 2) 9.5-10.5 dpc: PGCs leave the hindgut and move directly into the developing gonadal ridges. Acquisition/reacquisition of a motile phenotype, E-cadherin upregulation, perhaps mediating intercellular contact among pioneer PGCs, ECM interaction through $\beta 1$ integrin, SF-1/CXR4 and/or KL/kit chemoattractive action, are involved in this second phase. 3) 11.5-12.5 dpc: a final round of migration from the hindgut occurs through the dorsal mesentery into the gonads. Most of the factors involved in the second migratory stage continue to play a role. However, the fate of these late migrating PGCs remains uncertain. In particular, it is not known if they contribute to the germ cell population within the gonads, or if they are misallocated in other tissues to die by apoptosis, or if they have some other developmental fate.

\section{PGC proliferation}

Owing to mitotic proliferation during 8.5 to $13.5 \mathrm{dpc}$, the number of PGCs increases about 400 times from about 50 to 20,000 cells per embryo in 7-8 mitotic cycles (Tam and Snow, 


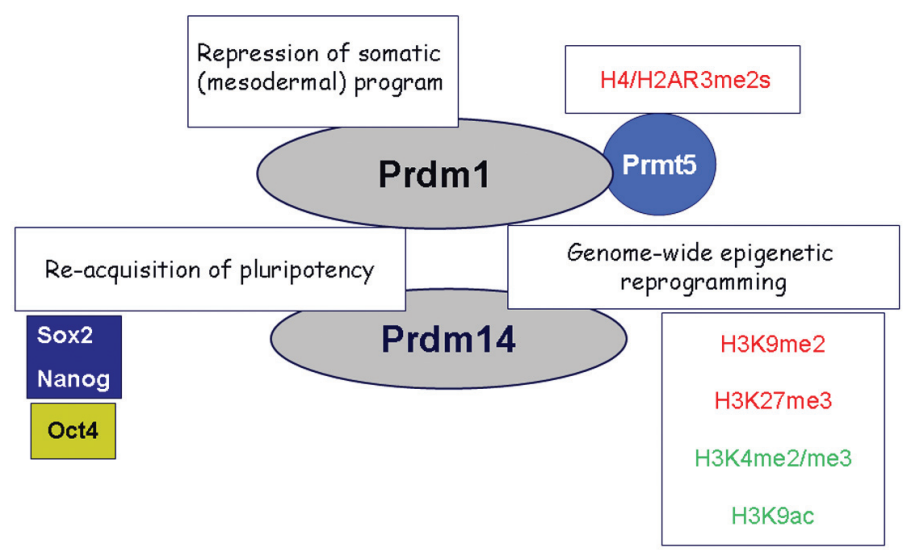

Fig. 3. Schematic representation of the main molecular events identified to be necessary for PGC specification in the mouse embryo. Histones in red and green are associated with repressed or active chromatin, respectively.

1981). PGC growth is sustained by a variety of soluble and membrane-bound growth factors (for a review, see De Felici et al., 2004). These factors prevent PGC apoptosis and/or stimulate their proliferation. PGCs undergo two mitotic blocks: the first at 7.5 up to $9.0 \mathrm{dpc}$ in $\mathrm{G}_{2}$ both in the female and male (Seki et al., 2007) and the second at 13.5-14.5 dpc in $G_{1} / G_{0}$ in the male (Western et al., 2008). Mutations affecting PGC proliferation as well some intracellular players controlling their mitotic cycle have been identified (De Felici et al., 2004; Sorrentino et al., 2007; Western et al., 2008; Spiller et al., 2009) (Fig. 4).

\section{Epigenetic dynamics}

As we have seen before, extensive genome-wide epigenetic reprogramming occurs in specified PGCs involving several modifications of histones associated with the repressed or active chromatin state (Seki et al., 2007; Hajkova et al., 2008). DNA dimethylation, $X$ reactivation in female $P G C s$ and erasure of parental imprinting are other critical and unique epigenetic modifications occurring in migratory and post migratory PGCs. Little is yet known about the exact significance of such changes and the

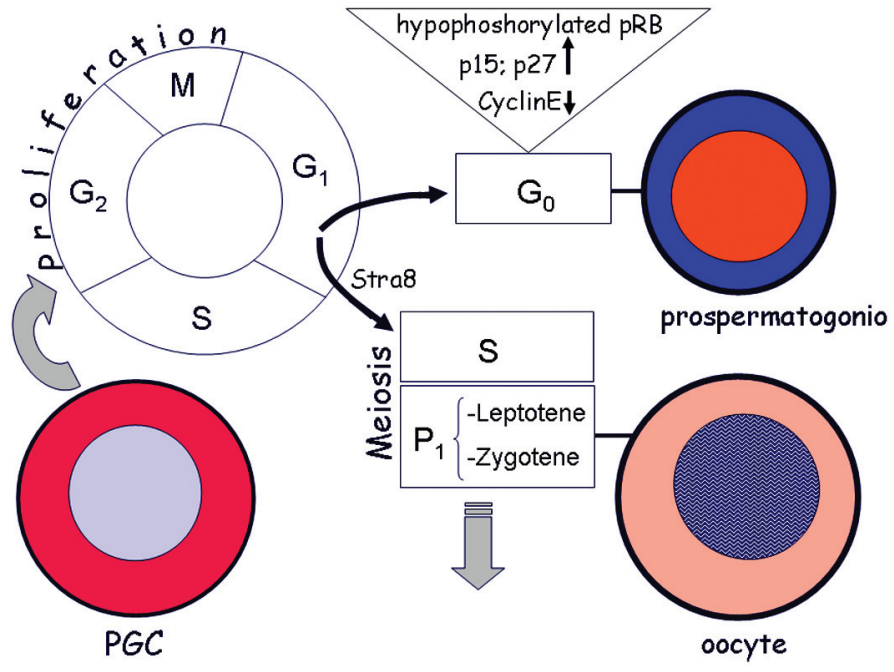

mechanisms involved, except that they are apparently active processes.

\section{Entering into meiosis}

Around $13.5 \mathrm{dpc}$ in the fetal testis, PGCs stop mitotic division and enter a period of mitotic quiescence in G0. Such quiescent male germ cells are now called prospermatogonia or gonocytes. At the same time, in the fetal ovary, the PGC cycle shifts from mitosis to meiosis. Two main views about meiotic entry have been put forward: 1) entering into meiosis occurs spontaneously and cell-autonomously in female PGCs after a certain number of mitotic cycles; in the fetal testis, meiosis is blocked by the action of a meiotic preventing substance (MPS) produced by somatic cells; 2) entering into meiosis in female PGCs is induced by a meiotic inducing substance (MIS) and it doesn't occur in fetal testis due to the absence of MIS and/or the presence of MPS.

Recent evidence indicates that retinoic acid (RA) produced by the mesonephros exerts MIS action in the fetal ovary, inducing PGCs to enter meiosis in an anterior-posterior direction. In the male, the P450 enzyme, active in somatic cells of the fetal testis, degrades RA and prevents PGCs entering into meiosis. An important target of RA is STRA8, a protein of unknown function whose action seems, however, crucial for the G1 mitotic-meiotic shift in female PGCs. It remains to be seen if RA is absolutely necessary for induction of meiosis in PGCs and if STRA8 really plays a role in the shift from mitosis to meiosis (for a review, see Bowles and Koopman, 2007) (Fig. 5).

\section{Stem cells from PGCs, and PGCs from stem cells}

Finally, two interesting aspects of PGC development have raised major interest among scientists in recent decades due to their implications for stem cell biology and for the formation of certain types of tumors called teratoma and teratocarcinoma. It is possible to derive ES (embryonic stem)-like cells called EG (embryonic germ)-cells from PGCs in culture and to produce PGCs from EG or ES cells in culture (for reviews, see Aflatoonian and Moore, 2006; Donovan and De Miguel, 2003). The molecular mechanisms of both processes have not been fully elucidated. We know, however, that LIF, KI and bFGF (or forskolin or RA) are
Fig. 4 (Left). The main processes and identified molecules controlling the arrest of the mitotic cell cycle in male PGCs into prospermatogonia or the shift from mitosis into meiosis in female PGCs.

Fig. 5 (Right). The recent model of entering into meiosis in female PGCs stimulated in an antero-posterior direction by retinoic acid (RA) produced by the mesonephros.

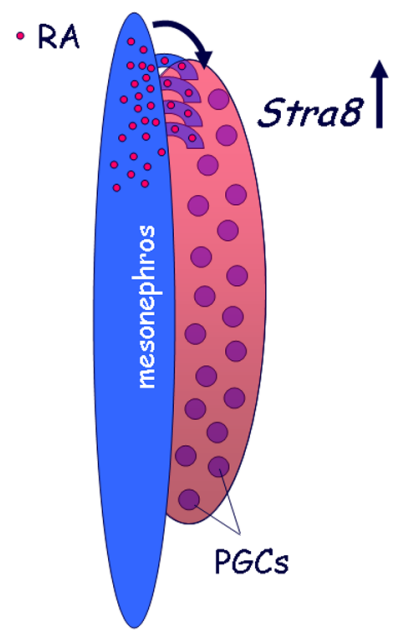


necessary for the transformation of PGCs in EG cells and that Blimp1 downregulation, Stat3induction, PTEN inhibition or ablation, likely $E$-Ras upregulation and bFGF-dependent upregulation and cytoplasmic-nuclear translocation of FGF receptor 3 favor, or are required for, this process (Durcova-Hills et al., 2006; our unpublished observations). While it is likely that all these factors cooperate to establish the self renewal and apoptotic independence of PGCs, their interrelationship and link to PGC intrinsic pluripotency have not been elucidated.

\section{Concluding remarks}

Progress in our understanding of PGC biology certainly benefited from the availability of modern techniques allowing the isolating and culturing of PGCs, to observe live cells moving within the embryo, to analyze gene expression in single cells, or the expression of thousands of genes in microarrays and to knockdown genes in a cell type specific manner. I remember, however, the amazingly simple instruments which Anne used for her studies in her personal-office-lab: an old stereomicroscope, a pair of forceps, some scissors and pipettes, were all that seemed she needed. For many years everywhere around the word, scientists discussing $P G C$ s are going to remember the results and intuitions of Anne McLaren. Following in her footsteps, we'll continue to face the exciting challenge of unraveling the secrets of germ cells "the most fascinating cells of all" as Anne loved to define them.

\section{References}

AFLATOONIAN, B. and MOORE, H. (2006).nGerm cells from mouse and human embryonic stem cells. Reproduction 132: 699-707.

BOWLES, J. and KOOPMAN, P. (2007). Retinoic acid, meiosis and germ cell fate in mammals. Development 134: 3401-3411.

DE FELICI, M., SCALDAFERRI, M.L., LOBASCIO, M., IONA, S., NAZZICONE, V., KLINGER, F.G. and FARINI, D. (2004). Experimental approaches to the study of primordial germ cell lineage and proliferation. Hum. Reprod. Update. 10: 197206.
DE FELICI M, SCALDAFERRI ML, and FARINI, D. (2005). Adhesion molecules for mouse primordial germ cells. Front. Biosci. 10: 541-551.

DONOVAN, J. P. and DE MIGUEL, M.P. (2003). Turning germ cells into stem cells. Curr Opin Genet Dev. 13: 463-471.

DURCOVA-HILLS, G., ADAMS, I.R., BARTON, S., SURANI, M.A. and McLAREN, A. (2006). The Role of Exogenous Fibroblast Growth Factor-2 on the Reprogramming of Primordial Germ Cells into Pluripotent Stem Cells. Stem Cells 24: 1441-1449.

HAYASHI, K., CHUVA DE SOUSA LOPES, S.M. and SURANI, M.A. (2007). Germ cell specification in mouse. Science 316: 394-396.

HAJKOVA, P., ANCELIN, K., WALDMANN, T., LACOSTE, N., LANGE, U.C. CESARI, F., LEE, C., ALMOUZNI, G., SCHNEIDER, R. and SURANI, M.A. (2008). Chromatin dynamics during epigenetic reprogramming in the mouse germ line. Nature 452: 877-881.

McLAREN, A. (1981). Germ Cells and Soma: a new look to an old problem. Yale University Press, New Haven, CT.

McLAREN, A. and LAWSON, K. (2005). How is the mouse germ-cell established? Differentiation 73: 435-437.

EKIY., YAMAJI, T., YABUTA, Y., SANO, M., SHIGETA, M., MATSUI, Y., SAGA, Y., TACHIBANA, M., SHINKAI, Y. and SAITOU, M. (2007). Cellular dynamics associated with the genome-wide epigenetic reprogramming in migrating primordial germ cells in mice. Development 134: 2627-2638.

SORRENTINO, E., NAZZICONE, V., FARINI, D., CAMPAGNOLO, L. and DE FELICI, M. (2007). Gene Expr Patterns 7: 714-721.

SOTO-SUAZO, M. and ZORN, T.M. (2006). Primordial germ cell migration: morphological and molecular aspects. Animal. Repr. 2: 147-160.

SPILLER, C., WILHEM, D. and KOOPMAN, P. (2009). Cell cycle analysis of fetal germ cells during sex differentiation in mice. Biol. Cell. (doi: 10.1042/ BC20090021).

TAM, P.P.L. and SNOW, M.H.L. (1981). Proliferation and migration of primordial germ cells during compensatory growth in mouse embryos. J. Embryol. Exp. Morphol. 64: 133-147.

WESTERN, P.S, MILES, D.C., VAN DEN BERGEN, J.A., BURTON, M. and SINCLAIR, A.H. (2008). Dynamic arrest of mitotic proliferation in fetal male germ cells. Stem Cells 26: 339-347.

YAMAJI, M., SEKI, Y., KURIMOTO, K., YABUTA, Y., YUASA, M., SHIGETA, M. YAMANAKA, K., OHINATA, Y. and SAITOU, M. (2008). Critical function of Prdm14for the establishment of the germ cell lineage in mice. Nature Genet. 40 : 1016-1022.
5 yr ISI Impact Factor $(2008)=3.271$

\section{For the latest research on} Epigenetics \& Development, see our latest Special Issue edited by Saadi Khochbin and Stefan Nonchev

http://www.intjdevbiol.com/web/contents.php?vol=53\&issue=2-3

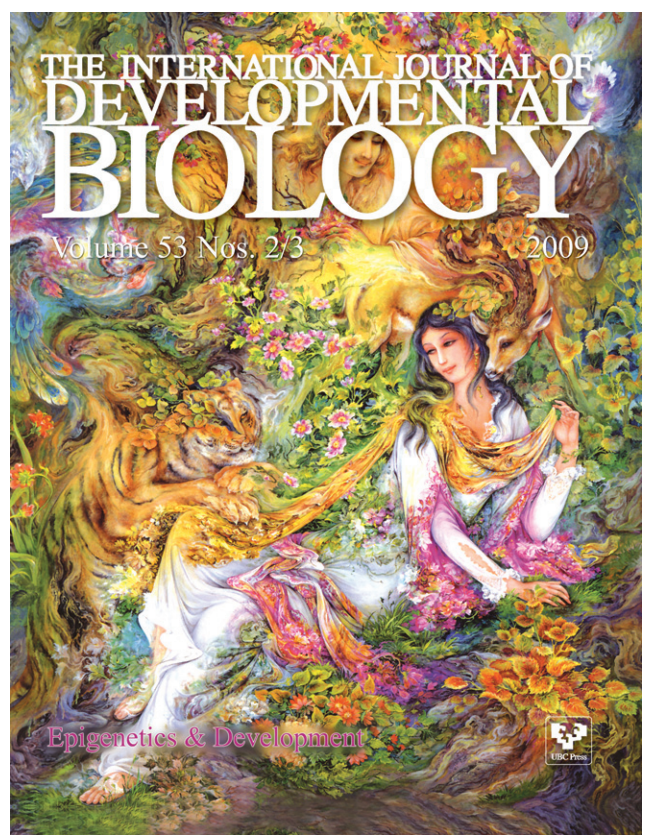




\section{Further Related Reading, published previously in the Int. J. Dev. Biol.}

See our recent Special Issue Mammalian Reproduction and Development, dedicated to honouring the career of Anne McLaren and edited by Brigid Hogan at: http://www.ijdb.ehu.es/web/contents. php?vol=45\&issue=3

See our Special Issue Pattern Formation edited by Cheng-Ming Chuong and Michael K. Richardson at: http://www.ijdb.ehu.es/web/contents.php?vol=53\&issue=5-6

In memoriam of Anne McLaren

Marilyn Renfree and Roger Short

Int. J. Dev. Biol. (2008) 52: 1-2

The distribution and behavior of extragonadal primordial germ cells in Bax mutant mice suggest a novel origin for sacrococcygeal germ cell tumors

Christopher Runyan, Ying Gu, Amanda Shoemaker, Leendert Looijenga and Christopher Wylie

Int. J. Dev. Biol. (2008) 52: 333-344

Interleukin-2 induces the proliferation of mouse primordial germ cells in vitro

Cristina Eguizabal, Maria D. Boyano, Alejandro Díez-Torre, Ricardo Andrade, Noelia Andollo, Massimo De Felici and Juan Aréchaga

Int. J. Dev. Biol. (2007) 51: 731-738

Primordial germ cell migration

Kathleen Molyneaux and Christopher Wylie

Int. J. Dev. Biol. (2004) 48: 537-543

Anne McLaren-a tribute from her research students

A G Clarke

Int. J. Dev. Biol. (2001) 45: 491-495

Anne McLaren as teacher

M Warnock

Int. J. Dev. Biol. (2001) 45: 487-490

The McLaren effect-a personal view

V E Papaioannou

Int. J. Dev. Biol. (2001) 45: 483-486

From embryo to ethics: a career in science and social responsibility. An interview with Anne McLaren

Brigid Hogan

Int. J. Dev. Biol. (2001) 45: 477-482

Mammalian reproduction and development. Special issue dedicated to honouring the career of Anne McLaren

Int. J. Dev. Biol. (2001) 45: 454-622

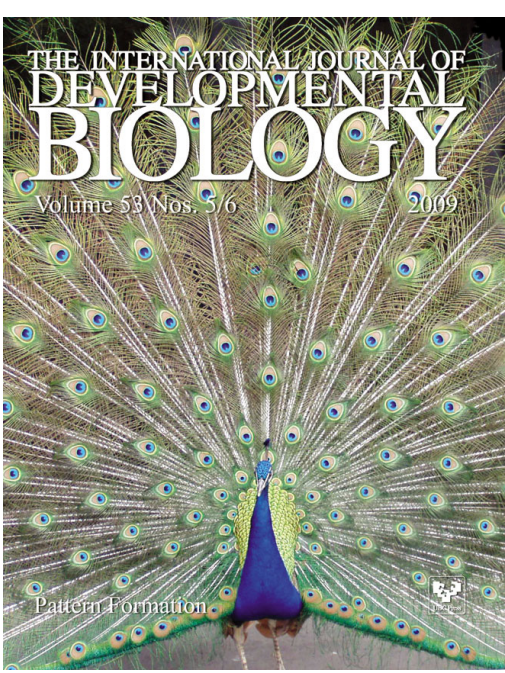

5 yr ISI Impact Factor $(2008)=3.271$

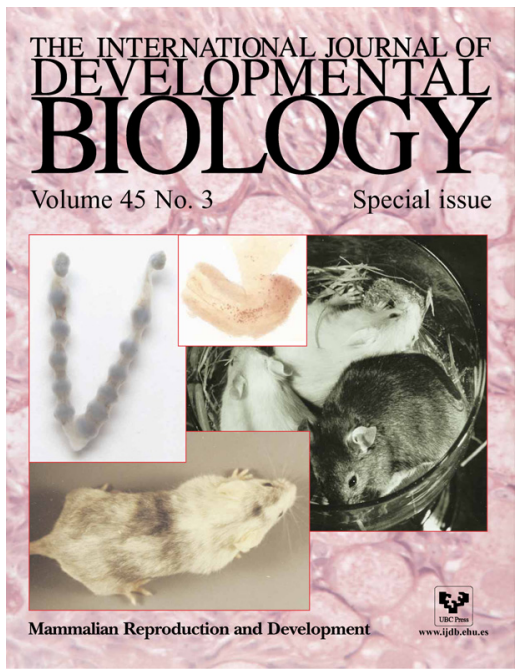

